[From a suite of papers with the title Second Nature, Bildung, and McDowell: David Bakhurst's The Formation of Reason, comprising papers by David Bakhurst, Jan Derry, Sebastian Rödl, and Paul Standish]

\title{
The Disenchantment of Education and the Re-enchantment of the World Paul Standish
}

The macaque washes a potato in a stream. It does this because it has seen the dirt come off as another macaque washed its potato, and it knows that clean potatoes taste better. The small child washes a plastic potato from a plastic vegetable set in a bowl of pretendwater. The child has seen the grownups doing this at the sink. He knows it is the kind of thing that grownups do. At the end of the washing, the macaque will eat the potato. Its action is the same as that of the macaque it has observed, but it has no sense that it is doing the same thing as that macaque. The child will not eat his potato for he knows it is plastic and not for eating: it is for pretending to do what the grownups do. Both macaque and child are engaged in a particular action; it is only for the child, however, that this is also understood under a general rule, only for the child that this is understood as something shared: this is what grownups do, this is what we do. Without the understanding of such a rule, plastic vegetables would make no sense. And toys have their fascination partly because of their disagreement with the general concept. In fact, it need not have been toy vegetables at all: some rounded stones from the beach and a bucket or who-knows-what would have done, and in fact that would have extended the joke-like pretending a pencil is a toothbrush.

It is the significance of these partly Aristotelian insights - of the relation of the

particular to the general concept, and of the fact that the human being is to be understood in terms of its form, its causa formalis - that Sebastian Rödl draws out so richly in 'Education and Autonomy', the preceding paper in the present discussion. The sharpness of his response here is provoked especially by the suggestion, in David Bakhurst and John McDowell, that baby human beings are 'mere animals', and that they are transformed from this state through a process of education or Bildung such that they become fully-fledged human beings. This constitutes an acquisition of second nature, our first nature being what we share with the brutes. Rödl tries to show, in response, that the baby is quite unlike the animal, whatever their relative abilities, in that the former has within it a potential that is actualised through education. The capacity for reason is there already in the child. It is not instilled by the teacher but actualised through the habits and 
content that the teacher provides. And the child, however incapable it may be in the early months of its life, is to be understood in terms of the form of the human: a baby is a human in virtue of its form. Education is a process of actualisation, not transformation. Not to see that a potential or latent capacity for reason is part of the reality of the human being, just as it is of the world itself, would risk fostering, or at least, giving space to, a reductive naturalism.

My contribution to this symposium begins and ends with questions that Rödl raises. The central part of the discussion that follows, however, considers responses to reductionism as these are found in the work of McDowell, the acknowledged 'hero' of Bakhurst's The Formation of Reason.

\section{Disentangling manoeuvres}

In recent writings, Hilary Putnam $(2002,2012)$ has drawn attention to the influence, during the middle decades of the last century, that logical positivism had on thinking in academic and professional fields outside philosophy. Thus, in the 1930s, the economist Lionel Robbins advanced the view that there could be no rational justification for the redistribution of wealth because such a policy would be based on value judgements and these, as the positivists had shown, lacked 'cognitive meaning':

In this way, the logical positivist claim that 'Why people respond favorably to certain facts and unfavorably to others is [merely] a question for the sociologist' (Ayer, 1954, p. 237) came to be regarded as 'undoubtedly correct' by a policy science whose recommendations affect the lives of literally billions of our fellow human beings. Ethical questions are the questions that most of us think it most important to discuss rationally and not irrationally. But if the logical positivist view that economists deferred to for such a long time were indeed correct, then the very idea of discussing value questions rationally would be ('cognitively') nonsense. (Putnam, 2102, pp. 38-39)

Putnam concedes that Robbins's adoption of this position did not prevent other economists from elaborating policies directed towards redistribution, but they also remained in the sway of positivism insofar as their case was advanced in cautiously conditional, means-ends judgments of the form: 'if you have such and such values, then such and such is the most feasible economic policy' (ibid.). The separation of fact and value, and the further assumption that values were essentially 'subjective', remained largely unchallenged. It is not difficult to see the ways that such assumptions have, in the decades that have followed, maintained their hold in matters of policy and practice, as well as in popular consciousness, in spite of the fact that within philosophy these views are now so widely discredited. Nor is it difficult to recognise, within educational policy and practice, a late flowering of verificationism in current conceptions of teaching, learning, and above all assessment.

In identifying the ways the positivists' claims have been dismantled, Putnam lights on the word 'entanglement', a notion that he finds explicit in McDowell (1988) and implicit in the work of Willard van Orman Quine, Morton White and others. He writes: "The failure of the "disentangling manoeuvre" that was supposed to split up thick ethical predicates into a value-free "cognitive" component and a cognition-free "emotive" 
component was first seen by Philippa Foot and Iris Murdoch, and then further discussed . . . by Stanley Cavell and more recently by John McDowell and myself' (Putnam, 2012, pp. 51-52). His point in listing these names is in part to draw attention to the diversity of philosophical traditions from which enlightenment can come. And it is to suggest that philosophy does not serve itself well when it thinks of itself as a collection of specialisms, along the lines of medical science: 'It is when different insights from different sources are connected with each other that philosophy truly educates us' (ibid.).

McDowell's diagnosis of the 'disentangling manoeuvre' was to find fuller expression in his highly influential book, Mind and World (1996), based on his John Locke Lectures, given at Oxford in 1991. McDowell connects the project of disentanglement with a more pervasive 'disenchantment'. The medical-therapeutic motif of 'diagnosis' provides an appropriate characterisation for one aspect of McDowell's project, but this combines with a more spiritually charged vocabulary, which suggests purposes of a somewhat different, more constructive kind: there is the need to exorcise a certain kind of philosophical demon; and beyond this there is a move - albeit that this is very carefully qualified - towards a partial re-enchantment of the world. McDowell is clear that we should continue to regard the earlier disenchantment, which came with the rise of science, as an advance and, further, that we must resist any 'crazily nostalgic attempt to re-enchant the natural world' (1996, p. 76). But at the heart of his constructive endeavour are questions of meaning and value, and of the ways these pervade our lives and world, and this indicates the kind of re-enchantment that is to be entertained. This brings him into partial conflict with certain mainstream currents of thought within the philosophical tradition from which he comes, albeit that his elaboration of his position is framed within the fundamentally Kantian categories of that mainstream. In the section that follows I shall briefly sketch some main features of his approach before offering, in the subsequent section, a series of criticisms. On the strength of these, I shall then revisit the idea of enchantment, with a view both to registering the importance of McDowell's project and to indicating the reasons why these are matters of some significance for education.

\section{McDowell and the space of reasons}

In the Afterword, Part III, to Mind and World McDowell identifies the diagnostic move he has proposed in the lectures as a response to a prevailing condition: 'What I suggest is that our philosophical anxieties are due to the intelligible grip on our thinking of a modern naturalism, and we can work at loosening that grip' (p. 177). Identifying the source of our difficulties may be one way of sensitising us to their recurrence, for they will surely recur. The recognition of anxiety is there also in the Introduction, where modern philosophy's preoccupation with problems of knowledge is seen as betraying something else:

it is helpful to see those apparent problems as more or less inept expressions of a deeper anxiety — an inchoately felt threat that a way of thinking we find ourselves falling into leaves minds simply out of touch with the rest of reality, not just questionably capable of getting to know about it. A problem about crediting ourselves with knowledge is just one shape, and not the most fundamental, in which that anxiety can make itself felt (pp. xiii-xiv). 
The preoccupation with knowledge in McDowell's book takes off from Wilfrid Sellars's distinction between the 'space of reasons' and the 'realm of law', the former characterised by relations of normative kinds, the latter by causal relations of the type studied in the natural sciences. Crucial to Sellars's position are the negative implications of this: "whatever the relations are that constitute the logical space of nature, they are different in kind from the normative relations that constitute the logical space of reasons' (p. Xv). What this dichotomy opens up is a question about the nature of experience, and this leads to the other starting point for McDowell. This is the Kantian distinction between receptivity and spontaneity, where the former is a matter of the impressions made upon our senses in experience and the latter the freedom of thought. In his book, Bakhurst follows McDowell in quoting the celebrated aphorism 'Thoughts without content are empty; intuition without concepts is blind', which is to be understood in a way that acknowledges the complexity of this interaction and, perhaps, the impossibility of disentanglement. This does not dispense, however, with the need to specify more clearly just how it is that thought connects with experience, especially if, as in Sellars's account, thought and experience are taken to operate within spaces that are logically distinct. In the course of the many efforts to do just this, it becomes clear that certain extreme positions are to be avoided — on the one hand, 'bald naturalism', which would understand everything in terms of the realm of law, and, on the other, 'rampant Platonism', which constitutes an extreme idealism. Even if one avoids such extremes, however, one finds oneself oscillating between, on the one hand, an emphasis on the structuring powers of the intellect and, on the other, an acknowledgement of the (so it seems) incontrovertible givenness of what is received through experience. McDowell's intention is to lead us away from this oscillation.

The main thrust of McDowell's account is to show that the space of reasons goes 'all the way down' in experience: 'Experiences have their content by virtue of the fact that conceptual capacities are operative in them, and that means capacities that genuinely belong to the understanding: it is essential to their being the capacities they are that they can be exploited in active and potentially self-critical thinking' (p. 66). The content of experience does not depend on the pre-conceptual deliverances of sensible experience upon which the understanding subsequently puts a construction; on the contrary, those experiences are themselves already structured by the understanding. This is explained further, and in more overtly ethical terms, through reference to the idea of a 'naturalism of second nature' (otherwise a 'naturalized platonism' (p. 91)), which draws upon Aristotle's account of the way that human beings' lives are naturally constituted by processes of ethical upbringing and the normative logical space into which these lead. The child washing plastic potatoes, we might say, is entering the space of reasons as this is manifested in the adult practice of washing potatoes, and the discontinuity of his practice with that of the adults (his potatoes are, after all, plastic), far from being simply a deficiency, demonstrates more fully his understanding of the general concept. Thus, in McDowell's terms, one has one's eyes opened to reasons at large by acquiring a second nature. The process of this acquisition is, he claims, fittingly named Bildung (p. 84)notwithstanding the fact that this notion remains badly underdrawn in his account. This is a shortcoming that Bakhurst's book addresses and partly overcomes. 
The necessity of Bildung helps to show the differences in sensible experience between human beings and other animals. While we share with (some) animals exposure to changes in the environment by which we are affected, animals cannot be said to enjoy their outer experience in the way that we do. A mark of this enjoyment would be, I take it, the fact that, unlike the macaque, the child washing potatoes is not only copying the activity of its parents but entering into self-conscious practices of representation and participation in community. It is not, on McDowell's account, that animals are automata, but the nature of their experience is vastly different from that of human beings because it is not structured by the space of reasons. The implication is that that structuring is already there in experience for the human being (it is an already-structured experience to which the child is introduced), though whether or not an individual will be fully alert to this will depend in part upon the level of her Bildung. In developing this idea, McDowell makes reference to Hans-Georg Gadamer's 'remarkable description of the difference between a merely animal mode of life, in an environment, and a human mode of life, in the world' (p. 115). The force of this contrast is to show that a life not structured by the space of reasons is lived not in the world but in an environment or habitat. In significant respects this recognition constitutes the culmination of McDowell's argument in that the space of reasons, in the light of which specific experiences are constituted, now comes to be understood in terms of an idea of the world itself.

A further consequence emerges from this. This is, once again following Gadamer, that the world is to be understood as inseparable from ideas of language and tradition. The concluding words of the main part of McDowell's text (the sixth of the lectures) state:

The feature of language that really matters is rather this: that a natural language, the sort of language into which human beings are first initiated, serves as a repository of tradition, a store of historically accumulated wisdom about what is a reason for what. The tradition is subject to modification by each generation that inherits it. Indeed, a standing obligation to engage in critical reflection is part of the inheritance. . . But if an individual human being is to realise her potential of taking her place in that succession, which is the same thing as acquiring a mind, the capacity to think and act intentionally, at all, the first thing that needs to happen is for her to be initiated into a tradition as it stands (p. 126).

It is this emphasis on tradition and world that marks the highpoint of the account that McDowell musters against the pressures of the dualism of reason and nature. In resisting that pressure he has, in a sense, been seeking to overcome those aspects of the philosophical background from which he comes, and by which he continues to find himself confronted, in that he sees that line of philosophical thought as in some respects moribund: he wants to protect us from a further 'outbreak of philosophy', to 'stop this kind of philosophy before it begins' (p. 183).

Notwithstanding the cogent and, in some ways, compelling nature of Rödl's criticisms, my own sense is that the broad lines of the argument from McDowell and Bakhurst are persuasive enough. Yet the manner of its pursuit, and indeed its very starting point, leave a number of questions unanswered. In the next section I detail some doubts. 


\section{Being in the world}

Let me begin by drawing attention to various ways in which McDowell's starting point in the discussion relies on ideas that are distinctively technical: the realm of law, the space of reasons and experience itself.

Early in the book, and in keeping with the tradition, experience is understood in terms of impressions made on sensibility. This is a technical usage, being plainly at odds with the way that 'experience' is commonly used. 'Experience' is a notoriously slippery word, but it is only in philosophy that it is used in quite this way. The usage is set up in terms of the presumption of a dichotomy between receptivity and spontaneity, which, at the start, is taken as axiomatic. The dangers of a reductionism where experience is understood primarily in terms of the deliverances of sense become plain enough, and McDowell's argument adroitly moves away from these. It moves towards an enriching of the notion of experience, especially through the recognition that the space of reasons goes all the way down. In the end the notion of experience (and of the space of reasons) is broadened in the light of its dependence upon the concept of world. All of this seems right, but the moves that are needed in order to demonstrate this are made more complex as a result of the technical understanding of experience that is adopted at the outset. It is worth acknowledging, moreover, the way that a residue of the metaphysics of res extensa and res cogitans is found in any crude contrasting of experience with thought. In fact, as McDowell helps to show, experience necessarily involves thought, but so too it is important to recognise that thinking is experience as well: when as an adult, in vacant and in pensive mood, Wordsworth lies on his couch and recalls his delight in rushing through the woods as a boy, these thoughts are more properly the content of his experience than are the deliverances of sense; while, conversely, that boyish experience, always more than animal delight, was itself surely structured early on by fantasies of adventure - at least, by something more than receptivity.

The idea of the realm of law also is problematic insofar as it harbours a contradiction. If the space of reasons goes all the way down, this must condition our experience of the realm of law no less. Or, to phrase this in stronger terms, there could be no experience of the realm of law that was not already within the space of reasons. Without its connection with the space of reasons it would be literally inconceivable. This is not for a moment to deny that human beings are vulnerable to changes in the environment over which they have no control and that they may not understand. But it is to reaffirm the insights of Wittgenstein's private language argument, to the effect that for something to count as an object of experience or thought it must be subject to public criteria. Wittgenstein's conception of criteria is broader and more language-sensitive than is the space of reasons, but the crucial point remains: the realm of law, insofar as it is conceivable by human beings, is subject to the space of reasons. This is not, to make the point in different terms, to make the absurd claim that if there were no human beings nothing would happen! It is to say that it is impossible to conceive of those happenings other than from a human point of view (and so, that any account of such happenings must be undertaken in human terms). This extends to the conceiving of entities in the world and of causal relations between them.

The space of reasons, a pivotal notion for the argument, presents problems of more wide-ranging kinds, and in my view it suffers from being excessively cerebral. 
There is an over-emphasis on the use of concepts and an under-sensitivity to other ways in which human behaviour can be rational. While there was reason initially to follow Rödl, Bakhurst and McDowell in their use of this terminology, it is time now for it to be disturbed - initially by way of two contrasts.

A first contrast that needs to be drawn is with the Wittgensteinian idea of rulefollowing and 'knowing how to go on'. The significance of this extends from the most elevated to the most basic aspects of human experience. Thus, the practice of sitting on a chair is eminently part of the rational behaviour of human beings, but it is not clear that this is well described in terms of the application of concepts or of the space of reasons. Of course, in special circumstances - the occurrence of persistent neck-pain perhaps-it can become something we reason about, but normally such activity is woven seamlessly into the background of what we are doing. Where it does become an object of our direct attention, there will always (still) be something else that hides from conceptualisation in the background of ongoing coping. Hence, the nomenclature of 'concepts' and 'reasons' is overplayed, with the result that an excessively cerebral emphasis is given to what is at the heart of human experience.

A second contrast is to be drawn between emphasis on concepts and emphasis on language, and here once again the former has the effect of weakening the case that is being made. Something along these lines appears to be conceded in the final lecture in Mind and World. McDowell writes: 'In these lectures I have concerned myself with thought; I have tried to describe a way of conceiving how thought bears on the world that would be immune to some familiar philosophical anxieties. And so far I have scarcely mentioned language' (p. 124). The framing of this acknowledgement is worthy of note, but we need to proceed carefully here if this picturing of philosophy's relation to language is to emerge clearly. In what is after all a very short paragraph, McDowell is considering how far the argument presented in the series of lectures has departed from analytical philosophy - specifically, from analytical philosophy as characterised by Michael Dummett, in which preoccupation with language is indeed taken as a defining feature: 'For Frege, as for all subsequent analytical philosophers,' Dummett writes, 'the philosophy of language is the foundation of all other philosophy because it is only by the analysis of language that we can analyse thought' (Dummett, 1978, pp. 442, quoted in a footnote in McDowell, 1996, p. 124). Dummett himself focuses on two 'principal functions' of language, as a means of communication and as a vehicle for concepts, neither of which should be taken as primary, he asserts, as both are fundamental. While McDowell does not, of course, deny the importance of these facets of language, he distances himself from Dummett's account by emphasising that what really matters is that language is a repository of tradition, 'a store of historically accumulated wisdom about what is a reason for what' (p. 126). It is acknowledgment of this inheritance of tradition in the acquisition of language, not the recognition of its communication functions, that is important. It is this that helps to dispel the sense of mysteriousness that otherwise attaches to the transformation from mere animal to human being. According this importance to language - however late in the series of lectures - constitutes McDowell's 'way of accepting the basic tenet of analytic philosophy', albeit that this is at 'some distance from any Dummett considers' (p. 125). 
But how satisfactory is this picture? It is instructive in this context to consider McDowell's response to a challenge along the lines I am advancing that is found in Rüdiger Bubner's 'Bildung and Social Nature' (Bubner, 2002). McDowell writes:

I do not understand why Bubner suggests that there is an opposition between 'Gadamer's hermeneutic conception' and 'the standard conviction of the analytic school, that is, the basic explanatory power of language'. Michael Dummett defines analytic philosophy in terms of the thesis that the philosopher of thought should be a philosopher of language. I do not object to the thesis, as Bubner implies. I object to the way Dummett recommends it. . . The upshot is a somewhat Gadamerian vindication of what Dummett identifies as the basic tenet of analytic philosophy. Indeed a conviction of the basic explanatory power of language seems appropriately attributable to the author of Part Three of Truth and Method. It is Gadamer who says 'man's relation to the world is absolutely and fundamentally verbal in nature' (McDowell, 2002, pp. 475-476).

The supposed resolution of the opposition here echoes the Gadamerian note that McDowell strikes at the end of the lectures in Mind and World, which purports to express the horizon constituted by tradition with the formulation: 'Initiation into a language is initiation into a going conception of the space of reasons' (McDowell, 1996, p. 184). But is this quite what Gadamer has in mind? And how far is it consistent with the Wittgensteinian insistence that there are a great many things that we do with language? The fundamentally 'verbal' nature of the human being's relation to the world is not exhausted by language's 'explanatory power'! It would perhaps become apparent, if we were to step back a little and take a broader perspective, that the question of language's place in philosophy is a contemporary expression of the ancient quarrel between philosophy and literature; we might think of the story of this quarrel as entering, in early analytic philosophy at least, a particularly cantankerous phase, with the subordination of language to logic, as is found, for example, in Bertrand Russell's theory of descriptions. Wittgenstein comes to the view that the most that can be said is that logic is constructed out of language. Such a move, which unseats the prevailing metaphysics, is iterated throughout ordinary language philosophy. Moreover, we might place the present discussion, given a further take on this, within the rift in philosophy that emerges in the wake of Kant, but with the recognition that the quarrel is preserved more clearly in the analytic development of the subject than in, say, the hermeneutic tradition or in Kierkegaard, Nietzsche or Heidegger. On the face of it, the gestures towards the connections between tradition and language that, following Gadamer, are made by McDowell are indeed very much to be welcomed, but the placing of language in relation to philosophy via Dummett creates an odd disjunction in the argument. McDowell's acknowledgement of his difficulty in understanding the 'opposition between "Gadamer's hermeneutic conception"" and "the standard conviction of the analytic school, that is, the basic explanatory power of language', does nothing to allay doubts along these lines. Hence, these gestures towards language and tradition, such as they are, are scarcely likely to dislodge the conception of concepts and reasons that has dominated the account.

As I have already indicated, a proper suspicion of the technical nature of the concepts that are the starting-point of the argument (experience, the realm of law, the 
space of reasons) would have made the move towards the richer, more holistic conception of world all the more natural. The book might then have begun where it ends. So why is it that the turn to Gadamer comes so late?

Gadamer's Truth and Method was originally published in German in 1960, and so, when McDowell wrote Mind and World, it was hardly new on the scene. In a sense the way is laid for the reading of Gadamer by the recognition, in the work of McDowell and in that of his colleague Robert Brandom, of the importance of Hegel, though McDowell's reference to that philosopher tends to be comparatively slight. Why, one wonders, does Mind and World not show greater faith in its inheritance of Wittgenstein, whose thoughts are summoned occasionally but filtered through the framework of analysis in such a manner as to deny the ways that they might have been enlisted at its starting point? Why, given the text's acknowledgement of the influence of Richard Rorty, and given Rorty's considerable success in renewing interest in John Dewey, is the work of Dewey not acknowledged, for this too would have taken the ground away from under the feet of the opening chapters - with arguments prepared more than half a century before? And why, given the critical importance of Gadamer, and of his account of world in particular, is Martin Heidegger's Being and Time, enormously influential for Gadamer as for so much Continental thought, not allowed to cast light on the problems being addressed? Being and Time, let us recall, was first published (in German) in 1927. Let me concentrate on the example of Heidegger as, in relation to the specific lines of McDowell's argument, it is perhaps the most telling.

We have seen how important the idea of world becomes for McDowell. The more or less phenomenological account that Heidegger develops in Being and Time depends, holistically, upon a notion of world that is especially rich and that contrasts with the idea of a mere environment - precisely the contrast that Gadamer exploits. A proper understanding of experience, and of its being pervaded by those conceptual linkages that are the space of reasons, is shown by McDowell to require a similarly rich conception of world. Impingements on sensibility are not to be understood in isolated terms but against the background of those linkages. In this sense the notion of world has a priority, as the always presupposed background to specific experience. Heidegger's method of elaborating this, in the early stages of Being and Time, involves revealing those existential structures that connect us in meaningful relationships of ongoing coping, where our use of things relates to 'equipmental-wholes', in purposive, necessarily meaningful activity.

A specific moment in the exposition of Heidegger's phenomenology is perhaps specially worthy of note, for the terseness of what is said undermines at a stroke the traditional metaphysics that is McDowell's starting point. Thus, in response to Kant's lament that it is a scandal of philosophy and of human reason in general that there is still no proof of an external world, Heidegger retorts that the 'scandal' is not that this proof has yet to be given, but that 'such proofs are expected and attempted again and again' (Heidegger, 1962, p. 249). But let us say a little more about how he reaches this position. Elaborating on the nature of our multiple involvements in the world, Heidegger claims to have avoided what are in effect the poles of the oscillation that McDowell seeks to overcome. The existential ontology that Heidegger develops might be said to accord with naturalism of a kind to the extent that it does not deny that there are entities present at hand; it does not deny that there are objects in the world; and it is attentive to things as 
things! Heidegger formulates his target instead in terms of what he calls 'realism': his position differs in principle from every kind of philosophically realist (or, say, metaphysical) 'position':

for realism holds that the Reality of the 'world' not only needs to be proved but also is capable of proof. In the existential assertion both of these positions are directly negated. But what distinguishes this assertion from realism altogether, is the fact that in realism there is a lack of ontological understanding. Indeed realism tries to explain Reality ontically by Real connections of interaction between things that are Real (p. 251).

Idealism is taken by Heidegger to fare rather better. But if the idealist thesis is to remain cogent, 'the ontological analysis of consciousness itself is prescribed as an inevitable prior task'. Only because Being is 'in the consciousness' can we also understand and conceptualise 'such characteristics of Being as independence, the "in-itself", and Reality in general. Only because of this are "independent" entities, as encountered within-theworld, accessible to circumspection' (ibid.). As Heidegger will later develop this thought, there is a mutual appropriation of 'man' and world through language. There is a fit between our ways of thinking and the contents of our thoughts, and this is generated through the nature of our needs and our purposive behaviour. It is on the strength of, and out of, this holistic being in the world that more abstract or theoretical forms of thought become possible, including such abstract thought as that of the realm of law.

Hubert Dreyfus's celebrated exegesis of Heidegger's thought has been the basis of a contestation of McDowell's views in ways that have become well known, especially in conjunction with the idea that emphasis on the space of reasons obscures the part played in human life by ongoing coping, an expression that has already been given some prominence. McDowell's response, with which Bakhurst concurs, has been to the effect that his account of the conceptual extends beyond what is consciously articulated and into the activity Dreyfus has in mind. But the extension 'downwards' of the space of reasons, which is the substance of McDowell's defence, seems to me once again a manifestation of the reduction of the verbal to the giving of explanations. Hence, my remarks above indicate some sympathy with Dreyfus's criticism, and yet I have found reason to dissent from Dreyfus and not just in matters of detail. ${ }^{1}$

Dreyfus's reading of Heidegger was shaped early on by the work of his fellow doctoral student Samuel Todes. This background of influence is generously acknowledged in Dreyfus's introduction to Todes's excellent Body and World (2001), which was published posthumously, some decades after the 1963 dissertation that was its origin. Todes' phenomenological approach is informed particularly by the work of Merleau-Ponty and Kant, and the abiding emphasis of his book is, precisely, on the fundamental role of ongoing coping in the human condition - an emphasis that becomes familiar enough, as we have seen, in the sustained reading of Heidegger that Dreyfus has provided. These accounts are apt to foreground qualities that we in some sense share with animals; and such qualities are then understood as somehow more basic. In the explicitly architectural conception that is developed, ongoing skilled coping figures as the ground floor of the edifice, with the upper storeys, which rest on this foundation, given substance by self-consciously constructed social institutions and, at a higher level still, by such 
matters as art and religion. And the whole is governed, so it seems, by an economy of desire and satisfaction. My objections to the position advanced in these texts are of two main kinds. In the first place, it relies on a kind of foundationalism, as the architectural imagery readily reveals. In the second, it is steeped in a kind of naturalism - to be specific, an economy of desire and satisfaction. I take these two features to be vulnerable to criticisms along Wittgensteinian and Heideggerian lines. The force of such criticism is to reverse the direction of dependence - that is, so to speak, to subvert the architecture: it is only in the light of the upper floors of the building that the nature and character of those below can be understood; it is only in virtue of those 'higher' values that the 'lower' aspects of human lives have the character that they do. This may look like a variant on the claim that the space of reasons extends downwards to our ongoing coping, but the emphasis on language as something broader than explanation reveals a more diverse and complex picture. Second nature is there from the start. It conditions the world into which the baby comes: the experience of a baby being suckled by a mother is different from that of a baby suckled by a machine.

Dreyfus has acknowledged his failure, at least in his earlier exegesis, to attend to the later parts of Being and Time, which foreground the theme of mortality and without which the sense of the earlier pages of that text is seriously distorted. This avoidance was occasioned by his sense of those passages as, so he puts it, something of an existentialist embarrassment. One consequence of this is an over-emphasis on, or mischaracterisation of, ongoing coping: it is not the ground floor of being in the world. Another is a celebration of notions of flow and harmony, which then become amplified in Dreyfus's reading of Heidegger's later work. The result is a Californian Heidegger. There is a loss of the sense of the human condition as unheimlich — as uncanny or not-at-home - and of its constitution as 'ecstatic', which is to say not purely present or self-contained. Such characteristics are plainly at odds with modern naturalism, and they pull strongly against the disentanglements it indulges.

The suspicion of the 'disentangling manoeuvre' of which Putnam speaks — with its splitting up of thick ethical predicates into a value-free 'cognitive' component and a cognition-free 'emotive' component - is, then, ruled out in advance in the very different metaphysics that Heidegger's thought generates. Hence, the exposure of the manoeuvre occurred rather earlier than Putnam suggests. Indeed it is already there in Nietzsche, and in Emerson and Thoreau before him. ${ }^{2}$ In McDowell's own words there is the occasional suggestion of regret that the tradition of philosophy he writes within had not been open earlier to such thoughts. Man and World was described by Richard Rorty as "pathbreaking', and the extent to which McDowell succeeds in bringing light to these thickets of argument is certainly to be admired, but one might wish that this had been done with a more open eye to the wider philosophical landscape - with a greater appreciation, that is, of 'different insights from different sources', in Putnam's words.

I am left with the feeling that Mind and World is a powerful intellectual achievement, in which a highly intelligent philosopher manoeuvres his way out of the impasses to which philosophy has led. Wittgenstein says words to the effect that our thinking sometimes ties us up in knots and that sometimes the movements that need to be made in order to untie the knots are more complicated than those that tied them. ${ }^{3}$ Beyond this artistry exemplified in the precision of McDowell's argument and expression, however, there is, in Wittgenstein, a sense of something else at stake: indeed, it may seem 
that Wittgenstein unravels the knots only to (allow himself to) become caught up in them again. Where, then, we must ask, does that lead?

\section{Re-enchantment and disappointment}

At various moments McDowell points to the sense of compulsion there is about the arguments in question, as though they were motivated by deeper anxieties, registering a fear that, as I noted above, we are 'simply out of touch with the rest of reality' (McDowell, 1996, p. xiii). In this respect the book's pondering of how it is that spontaneity can connect with the deliverances of receptivity might be said to be a manifestation of scepticism, where this is to be seen not primarily or exclusively as an epistemological problem but rather as a manifestation of what it is in the human condition that - continually, compulsively, as it were - calls itself into question. This is to touch on the line of thought that Stanley Cavell has sustained in his writings - not least in his readings of Wittgenstein and of Emerson and Thoreau (see, for example, Cavell, 1979, 1981, 1990).

Elaborating on Wittgenstein's account of following a rule, within philosophy and across the broader reach of human experience, Cavell attempts to diagnose that human tendency to seek something beyond the criteria that are ordinarily available to us, as if there were something necessarily deficient or disappointing in the circumstances of our lives. It is easy to see a manifestation of this within educational practice where the ordinary judgements of the teacher are disparaged in favour of what is supposedly the greater rigour of objective testing. Cavell sees our (moral) progress as depending not exactly on our overcoming this persistent doubt, but on our learning to understand and to live with it — not simply to brush it aside, for it will surely return, but not to be its captive. This makes possible the realisation of a partial re-enchantment that is faithful to the conditions of our ordinary lives and learning. It eludes the excesses of Romanticism, 'crazily nostalgic' as these sometimes became in their reaction against disenchantment, and is patiently attentive to the realities of our being in the world: there is an acknowledgement that values inhere in the world and that our sense of this will sometimes falter. While it is, in fact, a classic Romantic text, Coleridge's The Rime of the Ancient Mariner, that prompts one of Cavell's most poignant expressions of scepticism's existential importance and of what it is (partly) to emerge from its grip (Cavell, 1988), it was, nevertheless and by contrast, on his view, part of the achievement of the American writers, Emerson and Thoreau, that they succeeded in providing an account of our lives that deviated from Romanticism, that was free from nostalgia, but that could still envision our world as partly enchanted (see, for example, Cavell, 1981, 1990; Standish, 2003, 2004, 2006).

False re-enchantment is a standing temptation, then, in familiar passages of Romanticism, in the recurrent inflations of Heidegger's writing, and in Californian economies of satisfaction. It threatens also in educational policy and practice, steeped as it is at present in a kind of nihilism. I take examples of false reanimation to be found amongst the following: in over-anxious attempts to reintroduce 'values' into the curriculum; in the self-referential theorisation of certain forms of qualitative research (e.g., Denzin and Lincoln); and in overly emphatic specifications of aims and objectives, with the possibilities of a kind of idolatry that these bring (see Standish, 1999). Living well with our disappointment in criteria points to the best ways in which more cogent and 
properly meaningful practice might be generated. It points to the ways in which the muted re-enchantment of the world can be realised.

With these thoughts, let us return to Rödl.

\section{The actualisation of education}

As we saw at the start, Rödl is provoked especially by the suggestion that baby human beings are 'mere animals', subsequently to be transformed through a process of education or Bildung. The vehemence of his response is felt in his demonstration that, in contrast to the merely animal, the capacity for reason is there already in the child. But how are we to view the alleged error in McDowell and Bakhurst? Is the reference to 'mere animals' a structural weakness or an expression of more contextual significance? Might it, for example, be seen rather as a rhetorical move, designed to point up a difference that familiar accounts from developmental psychology sometimes underplay? We surely do not imagine that McDowell or Bakhurst would treat a dead baby as they might a dead cat or rat. Nor wouldthey be persuaded that their differentiation in this respect was merely a matter of superstition. So what turns on their use of the phrase, and what is achieved by its repudiation? A similar question might be raised about 'nature'inevitably a problem term, especially for the being whose nature is convention. Are there two natures, then, or just one? What is clear is that all the main parties to the present discussion join in the rejection of modern naturalism, where this is understood to involve the separation of fact and value and the assumption that values are essentially 'subjective'. Is what separates Rödl from McDowell and Bakhurst partly, then, just an issue of terminology? Rödl's view is plainly that there is more at stake: to see a separation into two natures involves a misunderstanding of the nature of human being, which must primarily be understood in terms of its form, incorporating those elements that are actual and those that are potential.It is not clear to me how this issue might be resolved, but I do think that progress can be made more generally in relation to three aspects of the discussion: first, by seeking a new angle on the idea of a second nature; next, by addressing more directly the ideas of reason, education, and autonomy; and, finally, by drawing out the significance of the themes of language and world.

Rödl does not disagree with McDowell and Bakhurst that something of crucial importance happens as the child is exposed to the influence of adults. It is through this that she starts to reason, and this is so whether or not this is, on Rödl's view, the actualisation of a power already there or, on McDowell's and Bakhurst's, the acquisition of something new (reason) on the strength of certain developing capacities in the child (sensibilities and behavioural responses). It is not clear to me why change of so profound a kind should not be seen as 'transformational', a word that Rödl wants to resist. The caterpillar is to be understood in terms of the form of the butterfly, but it surely has its transformations. If in the human context there is a rhetorical charge to 'transformation', then why necessarily resist this? In a more literary philosophical vein, Thoreau makes much of the seasonal transformations, the rebirths, through which animals go, with the loon bird losing its feathers, the snake sloughing its skin; and he sees it as crucial that, when the time has come, human beings go through their own non-seasonal changes. At another point in Walden he speaks of his bathing in the lake as a daily baptism-as if we should continually be prepared to let go of something to which we cling too much and be ready for something new, as it were in a series of little rebirths. And elsewhere again in 
that text, he writes of our acquiring not just a mother tongue but - at some later stage and perhaps in an ongoing, continuing way-also a 'father tongue' (see Standish, 2006). The phrase connotes a relation to our language in which we do not inhabit it seamlessly and without self-consciousness but where we can be brought up short by a word or a phrase, where we are called upon to look again at that phrase's significance and effects, and where at times we are not sure how to go on. This is crucial to our developing thought and judgement. Such moments, absent in the exchange of signs amongst animals (which do indeed seem to work more or less reliably, more or less like tools), are the means of imagination and the opening of culture. Moreover, it would be quite wrong to think of this acquisition of the father tongue as some kind of adolescent coming of age, for in a sense it is there from the start, in the child's first experimentations and play with words. In The Claim of Reason (1979), in the 'Excursus on Wittgenstein's vision of language', Cavell illustrates this with some brilliance. The child hears the word 'pumpkin', which connects somehow with that large orange thing that is there in the shops around Hallowe'en, but then wonders just how this relates to Mr Popkin who lives next door and whether it is a pumpkin because it is somehow pumped up. Open possibilities of association and connection are there already in the kinds of signs that human beings use. In consequence, entry into language is at the same time an opening for leaps of the imagination. The disagreements between rule and practice that Rödl identifies so evocatively in children's play are but a part of this broader, necessary aspect of language. So the point of this extended example is to show how there is a kind of secondness in this: words seem, as it were, to fold back on themselves or turn in new directions. This suggests a trajectory that is far from unilinear, that is not reducible simply to first and second developmental stages, but that is, in some sense at least, transformational in kind.

To identify these matters is to show something of what might matter in education. It is for good reason that the account of education in Rödl's paper is thin, in that this is not where its main focus lies. But it is worth drawing something out from this, for what is said here affects the conception of autonomy with which his discussion is engaged. Rödl is concerned with an underdescription at the most basic level - that of the baby; my concern is with the larger picture of reason that informs this.

The power of reason already in the child is actualised by her being brought into the habits and reasonings of the adults around her. Not to say more than this, however, is to work with a characterisation of reasoning that is decidedly loose and a characterisation of autonomy in only the 'minimal' sense. ${ }^{4}$ The habits and reasonings of the adults to which the child is exposed may be intellectually restricted or morally objectionable, but they will still serve to actualise her powers of reason. Fagin's 'school' for pickpockets (in Oliver Twist), a course in astrology or introduction to the rules of quidditch (in Harry Potter) would all seem sufficient. Yet none will qualify as education in any responsible sense, nor will they lay the way for any ideal of autonomy. They involve reason to the extent that reasons and explanations are advanced, but they fall well short of any more normatively rich conception, of which any credible conception of education surely stands in need. My sense is that such a conception cannot be gained without reference to content. Reason without content is empty and blind.

Now, as we saw earlier, McDowell's remarks regarding language as a repository of tradition support the idea that the space of reasons that the child enters is substantively rich - rich with traditions of thought and judgement, and with the topography of 
discipline and practice. Bakhurst's suggestion that the notion of initiation warrants further scrutiny - whether into the forms of knowledge, worthwhile pursuits, or the conversation of mankind - is, then, very much to the point. It is one of the achievements of The Formation of Reason that, in recognising the need for greater attention to the idea of initiation, it expands and enriches the notion of Bildung, which McDowell engages only in formalistic terms. In my Preface to the book, I drew attention to its appreciation of the embeddedness of Bildung in the facts of human life - of human finitude and sensibility, of human beings as subject to emotion and mood. This is elaborated in some detail through revealing practical examples, drawn especially from music and the arts, in which the significance of specific subject-matter comes to the fore. When it comes to the bigger picture, the account of Bildung that is generated is historically rich: with roots in Renaissance humanism and ultimately Ancient Greek thought, and with strong connotations of character formation, it is explicated as a process of self-making. Such a vision of freedom and reason gives purchase to the ideal of autonomy through the learner's growing acquaintance with substantive traditions of practice. It is, then, incumbent upon educators to ensure that this process is informed by plausible conceptions of the good, Bakhurst's account of which is resolutely affirmative and pluralistic.

Bakhurst finds connections between his own project and aspects of constructionism, but also with the work of R.S. Peters, Paul Hirst, and Robert Dearden. In the course of comparing his position with the latter group of philosophers, however, he identifies some significant differences, all of which help to clarify what he takes to be at stake. One such difference arises from his questioning how far conceptual analysis can take us in those questions in the philosophy of mind that are at the heart of the present symposium. While I am sympathetic to this criticism, I believe he does not sufficiently acknowledge the extent to which the main representatives of the London School were engaged in filling out some more normatively rich account of what reason, education, and autonomy might require and, hence, what initiation might amount to. In this it is important that they went well beyond what sometimes seemed their official methodology, and of course it is right to invoke the name of Michael Oakeshott as a key influence in this. ${ }^{5}$ What is interesting here particularly is the fact that the elaboration of reason in these ways cannot proceed very far in formal terms. Reason becomes something with a content, and evaluations of that content are internal to a better elaborated account. The more this content is emphasised, the more significant come to seem the particular kinds of habit and reasoning to which the child is exposed and the objects to which her attention is drawn: the gap between the power of reasoning in the child and its actualisation yawns more widely; and in the light of the continual traversing of this gap through education, it seems all the more reasonable to speak of transformation.

In some ways these considerations prompt the thought that the issue between Rödl and, especially, Bakhurst might be rendered in terms of the relative weight they give to the metaphysical and the ethical, a persistent question for the present symposium. Questions concerning the quality of the habits and reasonings into which children are inducted look like ethical rather than metaphysical matters. But I do not think this disentangling manoeuvre will do or that it would satisfy either of the parties concerned. They are right, in my view, to see these issues of mind and world as at the heart of education; and education itself, it can be added, is internal to the way the world becomes. 
My inclination has been to insert questions of language more forcefully into the discussion of mind, world and the formation of reason, and I have referred at times to Wittgenstein. But, as a tail-piece, I would like to bring to the discussion a telling criticism of Wittgenstein, which is particularly worthy of attention here. Rush Rhees, Wittgenstein's student and friend, argued that, for all the meticulous consideration of the variety of things we do with words, Wittgenstein did not take seriously enough the centrality in language of having something to say. Let me crystallise this by way of an anecdote, which I have elaborated in relation to these thoughts elsewhere (Standish, 2014). Imagine: You are sitting at your desk at home working, and a small child, not quite two years old, comes hurriedly into the room. He is distressed, struggling to say something, barely capable of finding any words at all, and you listen, discerning only fragments of sense. But, it is clear, he is imploring you to listen, repeating these same sounds excitedly, and finally they coalesce in a sentence you can understand: 'Ella put the dinosaur down the toilet.' Now dinosaurs, toilets, and big sisters (Ella) figure large in the mind of a two-year old, and it is plain that he is struggling to measure the gravity of what has happened. He has come to you, it turns out, not to seek your help in rescuing the dinosaur, for his mother, you soon work out, has already done that. He has come to you to tell you what has happened. He is registering from your reaction the importance of what has happened, and in so doing finding out something about what the world is like. But he is also, in finding something to say, discovering the world as something we can speak about and discovering himself as having something to say. These are crucial steps in discovering what the world is.

In his remarks about very small children, Rödl shows with some brilliance the ways that they enter into community with adults, and he is specific about what this entails. In particular he shows how the development of the general concept involves representation and the awareness that something is represented. This is true for the child before she can speak, and it is obvious that this ability accelerates spectacularly as she comes more fully into language. This is a highly important corrective to any assumption that language and the range of human gesture are to be understood exclusively or even primarily in functional or transactional terms. The realisation that things can be represented and that she may have something she wants to represent are breakthrough moments for the child, and they will be crucial not only to how she subsequently develops but to how the world comes to light. If the cow carries its environment in its stomach, the human being has the world in its tongue.

\footnotetext{
Notes

${ }^{1}$ I elaborated these views in an invited response to Dreyfus at a conference in Tokyo in 2003 (Standish, 2003a; see also Smeyers, Smith, and Standish, 2006, ch, 7).

${ }^{2}$ Of course the list might be extended back through history, taking in Hegel and Spinoza, and elements of Greek thought.

${ }^{3}$ Wittgenstein (1993, p. 193) writes: 'Philosophy unravels the knots in our thinking; hence its results must be simple, but its activity is as complicated as the knots that it unravels'.

${ }^{4}$ The contrast appealed to here is between miminal autonomy, as that normal, basic capacity for exercising judgement in virtue of which individuals can reasonably be praised or blamed for their actions,
} 
and the ideal of autonomy (sometimes called 'rational autonomy'), according to which a person's life would be lived in accordance with principles legislated by their own nature and in the light of reasoned judgement.

${ }^{5}$ For further discussion, see Bakhurst and Fairfield (2016). My own chapter in this volume, 'A Turn in the Conversation', expands on some of the points made here.

\section{References}

Ayer, A.J. (1957) Philosophical Essays (London, MacMillan).

Bubner, R. (2002) Bildung and Social Nature, in: N.H. Smith (ed.) Reading McDowell, pp. 209-216.

Cavell, S. (1979) The Claim of Reason (Oxford, Clarendon Press).

Cavell, S. (1981) The Senses of Walden: an Expanded Edition (Chicago, Chicago University Press).

Cavell, S. (1988) In Quest of the Ordinary (Cambridge, MA, Harvard University Press).

Cavell, S. (1990) Conditions Handsome and Unhandsome: The Constitution of Emersonian Perfectionism (Chicago, Chicago University Press).

Dummett, M. (1978) Truth and Other Enigmas (Cambridge, MA, Harvard University Press).

Dunne, J. (1993) Back to the Rough Ground: 'Phronesis' and 'Techne' in Modern Philosophy and in Aristotle (Notre Dame, London, University of Notre Dame Press).

Derry, J. (2008) Abstract Rationality in Education: From Vygotsky to Brandom, Studies in Philosophy and Education, 27.1, 49-62.

Dreyfus, H. (2005) Overcoming the Myth of the Mental: How Philosophers Can Profit from the Phenomenology of Everyday Expertise (APA Pacific Division Presidential Address 2005), Proceedings of the American Philosophical Association 79.2 (November 2005). Accessed on January $3^{\text {rd }} 2008$ at:

http://socrates.berkeley.edu/ hdreyfus/pdf/Dreyfus\%20APA\%20Address\%20\%201 $0.22 .05 \% 20 . p d f$

Dreyfus, H. (2007) The Return of the Myth of the Mental, Inquiry, 50.4, pp. 352-356.

Gadamer, H.-G. (1975) [1960] Truth and Method, $2^{\text {nd }}$ revised edition (New York, Continuum).

Heidegger, M. (1962) [1927] Being and Time, trans. J. Macquarrie and E. Robinson (Oxford, Blackwell).

McDowell, J. (1998) [1981] Non-Cognitivism and Rule-Following, in: Mind, Value and Reality (Cambridge, MA: Harvard University Press), pp. 198-218. Originally published in Wittgenstein: To Follow a Rule, ed. Steven H. Holtzman and Christopher M. Leich, pp. 141-72 (London, Routledge).

McDowell, J. (1996) Mind and World $2^{\text {nd }}$ edition ( $1^{\text {st }}$ edition, 1994) (Cambridge, MA, Harvard University Press).

McDowell, J. (2002) Responses, in: N. H. Smith (ed.) Reading McDowell: On Mind and World (London, Routledge), pp. 269-305.

McDowell, J. (2007) What Myth? Inquiry, 50.4, pp. 338-351. 
Putnam, H. (2002) The Collapse of the Fact/Value Dichotomy and Other Essays (Cambridge, MA, Harvard University Press).

Putnam, H. (2012) The Fact/Value Dichotomy and its Critics, in: N. Saito and P. Standish (eds) Stanley Cavell and the Education of Grownups (New York, Fordham University Press), pp. 37-52.

Putnam, H., Saito, N., and Standish, P. (2014) Hilary Putnam interviewed by Naoko Saito and Paul Standish, Journal of Philosophy of Education, 48.1, pp. 1-27.

Quine, W.V. (1951) Two Dogmas of Empiricism, in: From a Logical Point of View (Cambridge, MA, Harvard University Press), pp. 20-46.

Quine, W.V. (1963) Carnap and Logical Truth, in: The Philosophy of Rudolf Carnap, ed. P.A. Schilpp (LaSalle, Open Court Publishing Company), pp. 385-406.

Robbins, L. (1932) An Essay on the Nature and Significance of Economic Science (London: Macmillan).

Smith, N.H. (2002) Reading McDowell: On Mind and World (London, Routledge).

Standish, P. (1999). Education without aims?, in: R. Marples (ed.), Aims of Education, London: Routledge, pp. 35-49.

Standish, P. (2006) Stanley Cavell and the Teaching of Walden, Studies in Philosophy and Education, 25.1-2, pp. 145-157.

Standish, P. (2004) In Her Own Voice: convention, conversion, criteria, Educational Philosophy and Theory, 36.1, pp. 91-106.

Standish, P. (2003a) Coping Without Satisfaction: a response to Hubert Dreyfus, Journal of the Center for Philosophy, University of Tokyo.

Standish, P. (2003b) The Nature and Purposes of Education, in : R. Curren (ed.) The Blackwell Companion to Philosophy of Education, Oxford: Blackwell, pp. 221-231.

Taylor, C. (2002) Foundationalism and the Inner-Outer Distinction, in: N. H. Smith (ed.) Reading McDowell: On Mind and World (London, Routledge), pp. 106-119.

Todes, S. (2001) Body and World, with an introduction by H. Dreyfus (Cambridge, MA, MIT Press).

Wittgenstein, L. (1993) Philosophical Occasions (Indianapolis, Hackett).

White, M. (1956) Towards Reunion in Philosophy (Cambridge, MA, Harvard University Press). 
